Марченко В.М.,

президент

Нотаріальної палати України

УДК 347.1

DOI https://doi.org/10.32845/2663-5666.2020.3.5

\title{
ЗДІЙСНЕННЯ СУБ'ЄКТИВНИХ ЦИВІЛЬНИХ ПРАВ: НОТАРІАЛЬНИЙ АСПЕКТ
}

Постановка проблеми. Питання здійснення та захисту суб'єктивних прав завжди були ключовими питаннями цивільного права. Зокрема Є.О. Харитонов серед інших визначальних рис приватного (цивільного) права вирізняє високе місце приватного інтересу (увага акцентується на економічній свободі, вільному самовираженні та рівності товаровиробників, захисті прав власників у томі числі від сваволі держави) і наявності норм, які «звернені» до суб'єктивного права й забезпечують його захист $[1$, с. 9]. У цьому разі увага зосереджена саме на приватноправовому аспекті діяльності суб' єктів цивільного права, тобто на здійсненні й захисті їхніх інтересів і суб'єктивних прав.

Стан дослідження. Варто зазначити, що питанню аналізу поняття суб'єктивного цивільного права та шляхів його здійснення приділяється значна увага в спеціальній літературі. Зокрема, цим питанням присвячені праці таких учених, як М.М. Агарков, С.С. Алєксєєв, С.М. Братусь, В.П. Грибанов, О.В. Дзера, І.В. Жилінкова, О.О. Кот, Р.А. Майданик, Н.С. Кузнецова, З.В. Ромовська, Р.О. Стефанчук, Є.О. Харитонов та інших.

Метою статті є визначення особливостей здійснення суб'єктивних цивільних прав у рамках правовідносин, які підлягають нотаріальному оформленню.

Виклад основного матеріалу. Для національної доктрини поширеною залишається концепція юридичного позитивізму, згідно 3 якою держава розглядається як єдиний суб'єкт творення правових норм. Зокрема, М.В. Кравчук зазначає, що однією 3 необхідних передумов здійснення прав людини $\epsilon$ їх закріплення державою у формально визначених і загальнообов'язкових правилах поведінки - юридичних нормах [2, с. 104]. 3 таким підходом важко погодитися, адже не всі суб'єктивні права передбачені законом. Так, більшість природних прав людини належать людині від народження, при цьому незалежно від того чи визначені вони в законі. Крім того, концепція приватного права передбачає можливість діяти в будь-який спосіб, якщо це не заборонено або не порушує прав інших суб'єктів.

У зв'язку з цим варто підтримати підхід, згідно 3 яким на рівні закону неможливо визначити всі підстави виникнення суб'єктивного права та шляхи його здійснення. Натомість закон може визначити лише загальні принципи (засади) здійснення суб'єктивних прав i конкретний порядок їх здійснення в окремих випадках.

Як зазначає I.В. Жилінкова, суб'єктивне право $€$ гарантованим заходом можливої або дозволеної поведінки особи, змістовий складник якого становить низка відповідних правомочностей [3, с. 90]. Підтримуючи вказану тезу, варто зазначити, що для цивільного права не є характерним підхід «надавати дозволи» поводитися певним чином. Виходячи із цього, за загальним правилом, суб' єктивне цивільне право передбачає можливість для його носія діяти на свій розсуд у будь-який спосіб, якщо такі дії не шкодять іншим особам або не заборонені законом. Тобто зміст суб'єктивного права проявляється в наявній свободі його носія діяти 3 метою задоволення своїх потреб чи інтересів.

У цьому контексті Н.С. Кузнецова зазначає, що в межах суб'єктивного права кожен має можливість діяти на свій розсуд. Уповноважена особа є носієм свободи як стосовно своїх власних дій, так і щодо свободи від стороннього втручання [4, с. 255]. Власне, свобода $є$ підгрунтям і змістом цивільного права, яке передбачає можливість для встановлення обмежень з метою забезпечення справедливого правопорядку лише як виняток від загального правила.

Н.І.Мирошниковазазначає, щоцінністьбудь-якого суб' єктивного права полягає не лише в його наявності, а в можливості здійснення цього суб' єктивного права [5, с. 11]. Тобто без фактичної можливості для здійснення суб'єктивного права не можна повною мірою говорити про наявність відповідного права.

У юридичній літературі під здійсненням суб'єктивного цивільного права розуміється вчинення уповноваженою особою дій, спрямованих на використання можливостей, закладених у суб'єктивному праві, для задоволення потреб носія цього права або інших осіб [6, с. 224].

У цьому контексті варто зазначити, що в доктрині запропоновано підхід, згідно з яким для здійснення суб'єктивного цивільного права має існувати низка передумов, таких як достатній обсяг правоздатності й дієздатності в особи [7, с. 11; 8, с. 118]. Зокрема, Б.С. Щербина зазначає, що для здійснення суб'єктивного цивільного права необхідними є певні передумови: 1) наявність в особи достатнього обсягу правоздатності; 2) наявність в особи - суб'єкта права - належного обсягу цивільної дієздатності; 3) відсутність юридичних і фактичних перешкод для відповідної поведінки суб'єкта; 4) належний суб'єкт здійснення права [9, с. 15].

Видається, що такий підхід не є цілком обгрунтованим, адже суб'єктивне право вже дає можливості для його носія діяти певним чином і не передбачає жодних перешкод для здійснення волевиявлення. Крім того, наявність в особи суб'єктивного права є свідченням достатнього обсягу пра- 
воздатності, адже в інших обставинах (за межами правоздатності) вона не змогла б його набути. Виходячи із цього, суб' єктивне цивільне право як можливість його носія вільно діяти певним чином виключає необхідність наявності додаткових чинників (передумов), адже в такому разі суб'єктивного права просто не існуватиме до усунення всіх перешкод (наявності необхідних передумов).

Також у рамках дослідження видається за необхідне акцентувати увагу на одній з указаних передумов для здійснення права, а саме необхідності достатнього обсягу цивільної дієздатності для можливості здійснення суб'єктивного права. Цей аспект особливо важливий саме в контексті нотаріального оформлення правовідносин.

Якщо погодитися 3 тим, що обсяг дієздатності впливає на можливість здійснення суб'єктивного права, то можна дійти висновку, що недієздатна особа не має жодної можливості здійснювати належні їй майнові та особисті немайнові права. Тобто наслідком застосування вказаного підходу буде фактичне позбавлення особи, визнаної недієздатною, iii суб'єктивних прав, адже можливість здійснювати суб'єктивне право є складником самого права.

Такий наслідок не узгоджується з фактичним станом речей, адже в разі визнання особи недієздатною вона позбавляється лише можливості самостійно здійснювати належні їй права в рамках правочинів. Натомість здійснення іiі суб'єктивних прав відбувається за допомогою іншої особи - опікуна.

Крім того, недієздатна особа може самостійно здійснювати належні їй природні права (право на життя, здоров'я, недоторканність тощо). Натомість у разі порушення таких прав вона не зможе самостійно здійснювати їх юридичний захист.

Виходячи із цього, обсяг дієздатності варто розглядати не як передумову для здійснення суб'єктивного права, а як вагомий чинник, що впливає на визначення порядку здійснення суб'єктивних цивільних прав. Цей аспект здійснення прав $є$ важливим для вчинення нотаріальної дії, у зв'язку з чим нотаріуси завжди визначають обсяг дієздатності особи, яка до них звернулася. Механізм визначення нотаріусом обсягу цивільної дієздатності фізичної особи, зокрема, урегульовано ст. 44 Закону України «Про нотаріат» і главою 4 Порядку вчинення нотаріальних дій нотаріусами України, затвердженого Наказом Міністерства юстиції України від 22.02.2012 № 296/5.

Отже, наявність в особи суб'єктивного права $\epsilon$ достатньою підставою для його здійснення особою шляхом вибору моделі своєї поведінки. При цьому варто погодитися 3 думкою, що в приватній сфері зміст суб'єктивного цивільного права $\epsilon$ настільки широким, що його реалізація здійснюється за допомогою безмежного кола фактичних дій управненої особи, яка самостійно, на власний розсуд обирає сферу та способи задоволення своїх інтересів [10, с. 93].

Із цього приводу В.П. Грибанов указував, що оскільки зміст суб' єктивного права може бути охарак- теризований як загальний тип можливої поведінки уповноваженої особи, санкціонований об'єктивним правом, то зміст процесу його здійснення зводиться до вчинення уповноваженою особою реальних, конкретних дій, що випливають 3 особливостей цього конкретного випадку [11, с. 45-46]. Подібним чином О.О. Кот зазначає, що здійсненням суб' єктивного права вважається фактичне вчинення тих дій, актів реальної поведінки особи, можливість учинення яких надана цій особі шляхом закріплення за нею (набуття) суб' єктивного цивільного права [12, с. 18].

Виходячи з викладеного, суб'єктивне право знаходить свій зовнішній прояв в актах поведінки (діях) його носія.

Варто зазначити, що з приводу визначення способів волевиявлення (поведінки) особи під час здійснення нею цивільних прав у юридичній літературі немає узгодженої позиції. В одних випадках висловлюється позиція, що лише активні дії $є$ належним проявом здійснення права, в інших - обгрунтовується можливість здійснення суб'єктивних також шляхом бездіяльності (пасивні діі).

Так, Н.Ю. Фролова розглядає правову поведінку як складне, системне, соціально-правове явище, котре включає вольові дії, які спрямовані на досягнення соціально-значимої мети. Вона зазначає, що саме вольові дії є обов'язковим елементом правової поведінки [13, с. 57].

Іншої точки зору дотримується I.А. Полонка, яка зазначає, що правова поведінка - це не просто дія, а діяння, що включає й бездіяльність [14, с. 29]. У контексті цивільно-правових відносин Є.В. Вавілін зазначає, що в передбачених законом випадках мовчання визнається проявом волі вчинити правочин [15, с. 14-15]. Так само Д.В. Горбась указує, що окремі суб'єктивні права можуть здійснюватися у формі пасивних дій, зокрема в разі здійснення права на спадкування [16, с. 7].

У свою чергу, О.О. Кот уважає, що лише через активні дії можливе здійснення суб' єктивного цивільного права. Серед іншого він указує [12, с. 23], що «право на прийняття спадщини» не може вважатися суб' єктивним цивільним правом, а має розглядатися як секундарне право, яке кваліфікується в доктрині або як «недозріле право» [17, с. 11], або як різновид суб'єктивної правової можливості втручання особи в чужу правову сферу $[18$, с. $14 ; 19$, с. 138].

Видається, що в цьому разі варто враховувати зміст ч. 3 ст. 1268 Цивільного кодексу України (даліЦК), згідно з якою спадкоємець, який постійно проживав разом із спадкодавцем на час відкриття спадщини, уважається таким, щзо прийняв спадщчину, якщо протягом строку, установленого ст. 1270 ЦК, він не заявив про відмову від неї.

Отже, мова йде про юридичну презумпцію прийняття спадщини. Тобто особа, яка постійно проживала разом зі спадкодавцем і не вчиняла жодних активних дій, тим не менше вважається спадкоємцем. У цьому разі право на спадщину реалізується незалежно від волевиявлення, адже уповноважена особа автоматично вважається спадкоємцем. 
Більш того, за таких обставин в особи (спадкоємця) автоматично виникає право на спадщину (особа вважається такою, що прийняла спадщину), а не право на прийняття спадщини. Так, відповідно до ч. 5 ст. 1268 ЦК, незалежно від часу прийняття спадщини вона належить спадкоємцеві 3 часу відкриття спадщини. Отже, спадкоємець, який постійно проживав разом зі спадкодавцем, автоматично набуває право на спадщину з часу відкриття спадщини.

Ураховуючи викладене, можемо стверджувати, що в указаному випадку в особи (спадкоємця) виникає суб'єктивне право (право на спадщину) без учинення активних дій із ії боку.

Отже, в окремих випадках можна говорити, що законодавець уже вирішив питання здійснення права на прийняття спадщини певними спадкоємцями. Натомість у таких спадкоємців залишається право на відмову від прийняття спадщини, які вони можуть реалізувати лише через активні дії - шляхом подання заяви про відмову від прийняття спадщини.

Крім того, пасивні дї (мовчання) визначені як спосіб учинення правочину положеннями ЦК. Так, відповідно до ч. 3 ст. 205 ЦК, у випадках, установлених договором або законом, воля сторони до вчинення правочину може виражатися мовчанням.

У цьому контексті варто погодитися 3 думкою Р.А. Лідовець, який зазначає, що ст. 205 ЦК встановлює презумпцію того, що мовчання взагалі не $\epsilon$ юридичним фактом, але може ним стати у певних випадках, якщо сторони або закон нададуть йому такого значення, за таких же умов мовчання можна вважати способом вираження волі, тоді як за загальним правилом воно таким не $€[20$, с. 78$]$.

Прикладом законодавчого врегулювання таких випадків є ст. 764 ЦК, відповідно до якої якщо наймач продовжує користуватися майном після закінчення строку договору найму, то за відсутності висловлення заперечень наймодавцем протягом одного місяця договір уважається поновленим на строк, який раніше встановлений договором.

Крім того, відповідно до ч. 2 ст. 17 Закону України «Про оренду державного та комунального майна», у разі відсутності заяви однієї зі сторін про припинення або зміну умов договору оренди протягом одного місяця після закінчення терміну дії договору він уважається продовженим на той самий термін і на тих самих умовах, які передбачені договором.

Тобто в указаних випадках законодавством передбачена можливість продовження договорів у спосіб мовчання, яке визнається волевиявленням, спрямованим на вчинення правочину (продовження строку дії договору).

При цьому варто зазначити, що стосовно правовідносин, які потребують нотаріального оформлення, форма реалізації належних особам суб'єктивних прав завжди полягає в учиненні ними активних дій.

Це стосується всіх випадків: учинення односторонніх правочинів, укладення договорів і вчинення інших нотаріальних дій. Зокрема, якщо законодавством передбачено автоматичне прийняття спадкоємцем спадщини, оформлення належного йому права (отримання свідоцтва про право на спадщину) відбувається лише після звернення до нотаріуса. Тобто, навіть якщо мовчання (пасивні діï) і створює для особи правові наслідки, якщо вони підлягають нотаріальному оформленню, вона повинна вчинити активні вольові дії.

Варто також звернути увагу на те, що чинне законодавство передбачає дві підстави для участі нотаріуса в процесі здійснення особою належних цивільних прав: обов'язкову й факультативну.

У першому разі мова йде про встановлену законом обов'язковість нотаріального оформлення для закріплення відповідних правовідносин. До цієї категорії належать, зокрема, ситуації з обов'язковим нотаріальним посвідченням правочинів.

Так, обов'язковому нотаріальному посвідченню підлягають договори щодо розпорядження нерухомим майном, у тому числі земельними ділянками, щодо довгострокової оренди (найму) та позички будівлі іншої капітальної споруди, довічного утримання (догляду), управління нерухомим майном, про аліменти, щодо розпорядження окремими видами корпоративних прав і деякі інші. Нотаріальне оформлення також є обов'язковим при поділі спільного нерухомого майна або визначення часток у праві спільної власності й у механізмі здійснення спадкових прав. У багатьох випадках чинним законодавством вимагається нотаріальне посвідчення довіреностей, згод на виїзд дітей за кордон тощо.

У цьому контексті варто враховувати, що законодавець зазначає, що, за загальним правилом, недотримання вимоги щодо нотаріального посвідчення має наслідком недійсність правочинів. Зокрема, відповідно до ч. 4. ст. 203 ЦК, правочин має вчинятися у формі, установленій законом. Згідно 3 ч. 1 ст. 209 ЦК, правочин, який учинений у письмовій формі, підлягає нотаріальному посвідченню лише у випадках, установлених законом або домовленістю сторін. Відповідно до ч. 1 ст. 219 і ч. 1 ст. 220 ЦК, у разі недодержання вимоги закону про нотаріальне посвідчення правочину такий правочин $\epsilon$ нікчемним.

Виходячи з викладеного, можемо дійти висновку, якщо законодавством передбачена обов'язковість нотаріального оформлення правовідносин, то без звернення до нотаріуса здійснення суб'єктивних прав у рамках таких правовідн6осин $є$ неможливим.

Крім обов'язкової участі нотаріуса в процесі здійснення особою своїх цивільних прав, законодавством також передбачена можливість добровільного звернення до нотаріуса. Так, відповідно до ч. 4 ст. 209 ЦК, на вимогу фізичної або юридичної особи будь-який правочин із іï участю може бути нотаріально посвідчений.

У таких випадках нотаріус не відіграє обов'язкової ролі в процесі здійснення прав на рівні законодавчого закріплення, натомість його участь $є$ необхідною, виходячи з волі суб'єктів відповідних правовідносин.

У цьому контексті варто зазначити, що законодавство встановлює різні правові наслідки недотримання вимог при обов'язковому й добровільному залученню нотаріусів до оформлення правовідносин. 
Ключова відмінність полягає в правових наслідках порушення вимог щодо нотаріального оформлення. Якщо в разі з вимогою про обов'язкове нотаріальне оформлення правовідносин недотримання такої вимоги призводить до відсутності правовідносин, на які сподівалися сторони (нікчемність правочину, відсутність дозволів тощо), то в разі з порушенням домовленості про добровільне нотаріальне оформлення правовідносин таких наслідків не настає.

Так, незважаючи на те що, відповідно до ч. 1 ст. 209 ЦК, правочин, який учинений у письмовій формі, підлягає нотаріальному посвідченню лише у випадках, установлених законом або домовленістю сторін, нікчемність як наслідок порушення вимоги про нотаріальне посвідчення стосується лише правочинів, для яких вимога про нотаріальне посвідчення договору встановлена законом (ч. 1 ст. 220 ЦК).

За вказаних обставин недодержання сторонами вимог домовленості про нотаріальне посвідчення договору призведе до неукладеності договору. Такий наслідок закріплений у ч. 4 ст. 639 ЦК, відповідно до якої якщо сторони домовилися про нотаріальне посвідчення договору, щодо якого законом не вимагається нотаріальне посвідчення, такий договір є укладеним 3 моменту його нотаріального посвідчення.

Отже, можна констатувати, якщо законом передбачено обов'язкове нотаріальне посвідчення певних правовідносин, то здійснення суб'єктивного права в рамках таких правовідносин узагалі неможливе без участі нотаріуса, а в разі добровільності нотаріального оформлення досягнення правових результатів без участі нотаріуса ускладняється (договір уважатиметься неукладеним до моменту його нотаріального посвідчення, досягнення між сторонами домовленості про іншу форму договору чи судове вирішення спору).

Підсумовуючи викладене, можемо зробити такі висновки:

1. Здійсненням суб'єктивного права є вільна можливість у його носія діяти в рамках належного йому права на свій розсуд. При цьому можливість здійснювати суб'єктивне право є складником змісту самого права.

2. Для здійснення права не існує передумов, зокрема явності певного обсягу дієздатності й правоздатності особи. Суб'єктивне право вже передбачає можливості для його носія діяти певним чином i не передбачає перешкод (наявності передумов) для здійснення волевиявлення.

3. Обсяг дієздатності не впливає на можливість здійснення права, натомість $є$ визначальним для визначення способів його здійснення (самостійно чи iз залученням інших суб'єктів - опікунів, піклувальників тощо). Обсяг дієздатності завжди перевіряється нотаріусом під час здійснення нотаріальної дії.

4. Суб'єктивне право знаходить свій зовнішній прояв в актах поведінки (діях) його носія. Загалом законодавством передбачено можливість здійснення права як шляхом активних, так і пасивних дій. Натомість у правовідносинах, які підлягають нотаріальному оформленню, здійснення суб'єктивного права відбувається виключно шляхом учинення активних дій.

5. Якщо правовідносини повинні бути нотаріально оформленні (посвідчені правочини, оформлена спадщина тощо), здійснення відповідного суб' єктивного права особи неможливе без звернення до нотаріуса. У таких випадках участь нотаріуса є обов'язковим елементом процесу здійснення особою належного їй суб' єктивного цивільного права.

6. Чинне законодавство передбачає дві підстави для участі нотаріуса в процесі здійснення особою належних цивільних прав: 1) обов'язкову (якщо нотаріальне оформлення є обов'язковим, виходячи з вимог законодавства) і 2) факультативну (за бажанням суб'єктів правовідносин).

7. У першому випадку звернення до нотаріуса $є$ обов'язковим елементом здійснення права. При цьому недотримання вимоги про нотаріальне оформлення призводить до відсутності правовідносин, на які сподівалися сторони (нікчемність правочину, відсутність дозволів тощо).

8. У другому випадку участь нотаріуса $є$ необхідною, виходячи 3 волі суб'єктів відповідних правовідносин. Недодержання сторонами вимог щодо нотаріального посвідчення договору призводить до відсутності домовленості в належній формі (неукладеності договору).

\section{СПИСОК ВИКОРИСТАНОЇ ЛІТЕРАТУРИ}

1. Харитонов Є.О. Приватне право як «європейський концепт»: підгрунтя та кореляти. Часопис ияивілістики. 2016. Вип. 20. С. 8-16.

2. Кравчук М.В. Теорія держави і права. Проблеми теорії держави і права : навчальний посібник. 3-тє вид., змін, й доп. Тернопіль : Карт-бланш, 2002. 247 с.

3. Приватноправові механізми здійснення та захисту суб'єктивних прав фізичних та юридичних осіб : колективна монографія / В.Л. Яроцький, В.І. Борисова, I.В. Спасибо-Фатєєва, І.В. Жилінкова та ін. ; за наук. ред. проф. В.Л. Яроцького. Харків : Юрайт, 2013. 272 с.

4. Кузнецова Н.С. Развитие гражданского общества и современное частное право Украины. Вибрані nраиі. Київ : ПрАТ «Юридична практика», 2014. 541 с.

5. Мирошникова Н.И. Механизм осуществления субъективных гражданских прав. Ярославль : Ярослав. гос. ун-т, 1989. $82 \mathrm{c}$.

6. Цивільне право України : навчальний посібник / за заг. ред. І.А. Бірюкова, Ю.О. Заіки. Київ : Істина, 2004. 480 с.

7. Стефанчук М. О. Межі здійснення суб'єктивних цивільних прав : автореф. дис. ... канд. юрид. наук : 12.00.03 / Інститут держави і права ім. В.М. Корецького НАН України. Київ, 2006. 20 с.

8. Стефанчук Р.О. Цивільна правоздатність та дієздатність як необхідні передумови здійснення особистих немайнових прав фізичних осіб. Університетські наукові записки. 2006. № 3-4 (19-20). С. 114-123.

9. Щербинеа Б.С. Здійснення цивільних прав за законодавством України. Науковий вісник Міжнародного гуманітарного університету. Серія «Юриспрудениія». 2017. Вип. 29 (2). С. 12-16.

10. Приватноправові механізми здійснення та захисту суб'єктивних прав фізичних та юридичних осіб : колективна монографія / В.Л. Яроцький, В.І. Борисова, 
I.В. Спасибо-Фатєєва, I.В. Жилінкова та ін. ; за наук. ред. проф. В.Л. Яроцького. Харків : Юрайт, 2013. 272 с.

11. Грибанов В.П. Пределы осуществления и защиты гражданских прав. Осуществление и защита гражданских прав. 2-е изд., стереотип. Москва : Статут, $2001.411 \mathrm{c}$.

12. Кот О.О. Здійснення та захист суб'єктивних цивільних прав: проблеми теорії та судової практики : монографія. Київ : Алерта, 2017. 494 с.

13. Фролова Н.Ю. Правомерное и неправомерное поведение как парные юридические категории: общетеоретический аспект : дисс. ... канд. юрид. наук : 12.00.01. Белгород, 2010. 197 с.

14. Полонка I.А. Генезис сутності правової поведінки та пропозиції щодо поняття. Науковий вісник Міжнародного гуманітарного університету. Серія «Юриспруденція». 2014. № 10-2. Т. 1. С. 28-30.

15. Вавилин Е. В. Осуществление и защита гражданских прав / РАН. Ин-т государства и права. Москва : Волтерс Клувер, 2009. 338 с.
16. Горбась Д.В. Здійснення суб'єктивних цивільних прав фізичних осіб: поняття, способи, межі : автореф. дис. ... канд. юрид. наук : 12.00.03. Київ, 2009. $20 \mathrm{c}$.

17. Майданик Р.А. Проблеми регулювання довірчих відносин у цивільному праві : автореф. дис. ... докт. юрид. наук : 12.00.03. Київ, 2003. 28 с.

18. Борисова В.I. До проблеми самостійних правових можливостей суб'єктів цивільних правовідносин. Актуальні проблеми приватного права : матеріали Міжнар. наук.-практ. конф., присвяч. 92-й річниці з дня народження докт. юрид. наук, проф., чл.-кор. АН УРСР В.П. Маслова, 28 лют. 2014 р. Харків, 2014. С. 12-14.

19. Гринько П.О. Поняття секундарного права. Унiверситетські наукові записки. 2011. № 2. С. 130-140.

20. Лідовець Р.А. Мовчання та конклюдентні дії: спільні та відмінні риси. Актуальні проблеми вдосконалення чинного законодавства Украӥни : збірник наукових статей. Випуск XV. Івано-Франківськ, 2005. С. 77-81.

\section{Марченко В.М. ЗДІЙСНЕННЯ СУБ'СКТИВНИХ ЦИВІЛЬНИХ ПРАВ: НОТАРІАЛЬНИЙ АCПЕКТ}

Стаття присвячена аналізу питання участі нотаріуса в процесі здійснення суб'єктивних цивільних прав у рамках учинення нотаріальних дій. Питання здійснення та захисту суб'єктивних прав завжди були ключовими для цивільного права. Визначальними рисами приватного (цивільного) права є високе місце приватного інтересу та наявності норм, які забезпечують здійснення й захист суб'єктивного права.

Під здійсненням суб'єктивного права варто розуміти наявність вільної можливості в його носія діяти в рамках належного йому права на свій розсуд. Для здійснення права не існує передумов, зокрема наявності певного обсягу дієздатності й правоздатності особи. Суб'єктивне право вже передбачає можливості для його носія діяти певним чином і не передбачає перешкод (наявності передумов) для здійснення волевиявлення.

Суб’ єктивне право знаходить свій зовнішній прояв в актах поведінки (діях) його носія. У правовідносинах, які підлягають нотаріальному оформленню, здійснення суб'єктивного права відбувається виключно шляхом учинення активних дій. Якщо правовідносини повинні бути нотаріально оформленні, участь нотаріуса $\epsilon$ обов'язковим елементом процесу здійснення особою належного їй суб'єктивного цивільного права.

Чинне законодавство передбачає дві підстави для участі нотаріуса в процесі здійснення особою належних цивільних прав: 1) обов'язкову (якщо нотаріальне оформлення є обов'язковим, виходячи з вимог законодавства) і 2) факультативну (за бажанням суб'єктів правовідносин).

У першому випадку звернення до нотаріуса $є$ обов'язковим елементом здійснення права. При цьому недотримання вимоги про нотаріальне оформлення призводить до відсутності правовідносин, на які сподівалися сторони (нікчемність правочину, відсутність дозволів тощо).

У другому випадку участь нотаріуса $€$ необхідною, виходячи з волі суб'єктів відповідних правовідносин. Недодержання сторонами вимог щодо нотаріального посвідчення договору призводить до відсутності домовленості в належній формі (неукладеності договору).

Ключові слова: здійснення суб'єктивного цивільного права, нотаріальне оформлення, правочин, дієздатність, правоздатність.

\section{Marchenko V.M. EXERCISE OF SUBJECTIVE CIVIL RIGHTS: NOTARY ASPECT}

The article is devoted to the analysis of the notary's participation in the subjective civil rights exercise in the framework of notarial acts. Issues of the exercise and protection of subjective rights have always been central to civil law. The defining features of private (civil) law are the high place of private interest and the existence of rules that ensure the exercise and protection of subjective law.

The exercise of a subjective right is a free opportunity for person to act within the scope of his right to his own discretion.

There are no prerequisites for the exercise of the right, in particular the certainty of a person's capacity. A subjective right already provides for the possibility to act in act in one way or another and does not imply interference for the exercise of will.

Subjective law finds its external manifestation in the acts (actions) of person. In legal relations that are subject to notarization, the exercise of subjective law occurs solely by taking active action.

In cases where the legal relationship should be notarized, the participation of a notary is a necessary element of the process of realization subjective civil law.

The current legislation provides for two reasons for the notary's participation in the process of exercising of civil rights by a person: 1) compulsory (if notarization is mandatory based on the requirements of the law) and 2) optional (at the request of persons). 
In the first case, access to a notary is a mandatory element of exercise of the right. At the same time, failure to comply with the requirement of notarization leads to the absence of legal relations on which the parties hoped (void transaction, lack of permits, etc.).

In the second, the participation of the notary is necessary based on the will of the subjects of the relevant legal relationship. Failure of the parties to comply with the requirements for notarization of the contract leads to the lack of agreement in the proper form (failure to conclude the contract).

Key words: subjective civil law enforcement, notarization, legal transaction, legal capacity. 